\title{
Anti-diabetic activity by invitro inhibition of $\alpha$-amylase enzyme and phytochemical screening of Phyllanthus niruri.
}

\author{
Abina Rose Babu', Ashna Sunny', Diva Brijit John', Shweta Sharma ${ }^{1 *}$ \\ $1^{*}$ Department of Life Sciences, Kristu Jayanti College - Autonomous. \\ Corresponding author: abirose504@gmail.com
}

\begin{abstract}
Phyllanthus is a large genus of shrubs, trees and rare herbs of the family Euphorbiaceae, comprising more than 600 species [1]. The aim of this project was to identify the phytochemicals present in P. niruri and the antidiabetic activity of the ethanolic extracts of the plant. The phytochemical analysis for alkaloids, flavonoids, anthraquinone, phenols, saponins, tannins, alkaloids, total phenolics, total flavonoids, carbohydrates and amino acids were made by following standard procedures. The antidiabetic property of the plant extract was evaluated using insulin as standards through inhibition of alphaamylase enzyme activity. The presence of saponins, alkaloids, tannins, flavonoids, phenols, terpenoids, carbohydrates, coumarins, anthraquinones and amino acids was observed. The total phenolic content in the extract was measured using catechol (standard) and a graph was plotted with concentration on $\mathrm{X}$ axis and absorbance on the $Y$ axis. The total phenolic content was calculated. The calibration curves of $\alpha$-amylase inhibition of Insulin and P. niruri was used to calculate the IC50 value.
\end{abstract}

The major outcome of the study indicated that the plant extract has potent antidiabetic activity. The standard drug insulin at highest concentration $(100 \mu \mathrm{g} /$ $\mathrm{ml}$ ) showed $72.82 \%$ inhibitory effects on the $\alpha$-amylase activity with an IC50 value $62.49(\mathrm{\mu g} / \mathrm{ml})$. The ethanolic extracts of $P$. niruri at highest concentration showed $52.17 \%$ inhibitory effect on $\alpha$ - amylase activity with an IC50 value 92.69 . The study resulted as P. niruri is rich in phytochemicals alkaloids, saponins, flavonoids phenols, terpenoids, carbohydrates, amino acids, tannins, anthraquinone, coumarins that have antioxidant and antimicrobial activity

Hence, corroborates the use of P. niruri can be used traditional medicine as a anti-diabetic and have beneficial role for human health.

\section{Introduction}

The medicinal plant are emerging as a boon in therapeutic aids and have beneficial role for human health. Diabetes mellitus is a most common disease increasing in India and even affecting all parts of the world. Several medicinal plants are showing anti diabetic activity. [2,3]. Previous reports reported several plant species served as a hypoglycaemic such as, Trigonella foenum graecum, Momordica charantia, , Opuntia streptacantha, Gymnema sylvestre, Polygala senega Allium sativum, Citrullus colocynthis Ficus bengalensis and Aloe vera (4).The approaching therapeutic to control diabetes is to decrease the level of postprandial glucose level. The level of glucose is regulated by many carbohydrates -hydrolyzing enzymes present in oral cavity and intestinal lumen. Medicinal plants emerges out potent source of therapeutic aids against diabetes. It is shown that there significant association between phytochemicals (flavonoids, tannins and phenolic compounds) and inhibition of a-amylase and $\alpha$-glycosidase activities. Among phytochemicals phenolic compounds have a inhibitory effect on keys enzymes hydrolysing carbohydrates $(5,6)$

Therefore, the present study will explore the antidiabetic effect of P. niruri. P. niruri may potentially be an important natural product in therapy of diabetes. In addition, we will screen the secondary metabolites present in P. niruri.

\section{Materials and Methods}

\section{Sample Collection}

The healthy plants were collected from Kerala and Karnataka. The collected plant material was washed well, and shade dried. The dried plants were then grinded it into a fine powder form. The fine powder was collected and used for crude drug in different solvents by Soxhlet extraction method.

\section{Extraction of Phyto constituents By Soxhlet Extraction}

\section{Soxhlet apparatus}

$20 \mathrm{~g}$ of the plant powder was taken and packed in Whatman filter paper and placed in the Soxhlet main jar. The solvent ( $50 \%$ ethanol) was poured into the round bottom flask and extract condensation under reduced pressure and controlled temperature of $75^{\circ} \mathrm{C}$ and boiled using a heating mantle.The extraction process takes about 7-8 hours. The final solvent is then evaporated till it yields a brown /green waxy extract; this extract is then stored in refrigerator for further use.

Quantitative estimation of primary and secondary metabolites of P. niruri 


\section{Test For Saponins}

$5.0 \mathrm{ml}$ of distilled water was mixed with aqueous crude plant extract in a test tube and it was mixed vigorously. The frothing was mixed with few drops of olive oil and mixed vigorously, and the foam appearance showed the presence of saponins.

\section{Test For alkaloids:}

Hager's test: To $1 \mathrm{ml}$ of the plant extract, $3 \mathrm{ml}$ of Hager's reagent (saturated aqueous solution of picric acid) was added. Appearance of yellow coloured precipitate indicated presence of alkaloids.

Wagner's test: $1 \mathrm{ml}$ of Wagner's reagent was added to $2 \mathrm{ml}$ of plant extract along the sides of test tube. A reddish- brown precipitate indicates the presence of alkaloids.

\section{Test For Phenols}

Ferric chloride test: 3-4 drops of ferric chloride solution were added to $2 \mathrm{ml}$ of the plant extract. Appearance of bluish- black colour indicated the presence of phenols.

\section{Test For Terpenoids}

Salkowski's test: $5 \mathrm{ml}$ of the extract was mixed with $2 \mathrm{ml}$ of chloroform, and $3 \mathrm{ml}$ of concentrated sulphuric acid was added from the sides. A reddish- brown colouration at the interface of the liquids showed the presence of terpenoids.

\section{Test For Flavonoids}

Alkaline reagent test: $2 \mathrm{ml}$ of the crude extract was mixed with few drops of $\mathrm{NaOH}$ solution, which forms an intense yellow colour solution which disappears on the addition of dilute acid. This indicates the presence of flavonoids

Lead Acetate test: $2 \mathrm{ml}$ of the extract was mixed with lead acetate solution, the appearance of yellow colour precipitate indicated the presence of flavonoids.

\section{Test For Carbohydrates}

Molisch's test: $2 \mathrm{ml}$ of the plant extract was mixed with few drops of molisch reagent and concentrated sulphuric acid was added along the sides of the testtube. A violet colour ring formation indicates the presence of carbohydrates.

Fehling's test: $2 \mathrm{ml}$ of the extract was mised with fehlings solution $A$ and $B$, and heated in a boiling water bath. Appearance of red precipitate indicates a positive result.

Benedicts test: $2 \mathrm{ml}$ of the plant extract was mixed with $3 \mathrm{ml}$ of benedicts solution and heated in a boiling water bath. Appearance of reddish- brown precipitate shows positive result.
Barfoed's test: $2 \mathrm{ml}$ of plant extract was mixed with $3 \mathrm{ml}$ of Barfoed's reagent was added and heated. Development of brick red precipitate indicates positive result.

Seliwanoff's test: $2 \mathrm{ml}$ of the extract was mixed with $2 \mathrm{ml}$ of Seliwanoff's reagent and the solution was heated in a boiling water bath for 2 minutes. Development of red colour indicates a positive result.

\section{Test for Amino Acids}

Ninhydrin test: Two drops of ninhydrin solution are added to $2 \mathrm{ml}$ of the plant extract. Appearance of purple colour indicates the presence of amino acids.

\section{Test for Proteins}

Biuret test: $2 \mathrm{ml}$ of plant extract is treated with $1 \mathrm{ml}$ of biurets reagent. Pink colour ethanolic layer indicates the presence of protein.

\section{Test for Anthraquinone}

Borntrager's test: To $2 \mathrm{ml}$ of extract, $3 \mathrm{ml}$ of chloroform is added and shaken, chloroform layer is separated, and ammonia solution is added to it. Pink colour indicates presence of anthraquinone.

\section{Test for Cardiac Glucosides}

Keller- Killani test: To $2 \mathrm{ml}$ of the extract $3 \mathrm{ml}$ of glacial acetic acid was added and 2 drops of ferric chloride was added, and the contents were transferred into a test tube containing $2 \mathrm{ml}$ of concentrates sulphuric acid. Reddish brown colour at the junction of 2 layers indicates a positive result.

\section{Test for Tannin}

Ferric chloride test: $0.5 \mathrm{~g}$ of plant powder is boiled in $20 \mathrm{ml}$ of distilled water. To this filtrate few drops of $5 \%$ ferric chloride solution are added. A dark blue colour indicates the presence of tannins.

\section{Test For Coumarins}

Sodium hydroxide test: $2 \mathrm{ml}$ of the extract is mixed with $3 \mathrm{ml}$ of $\mathrm{NaOH}$ solution. Appearance of yellow colour indicates the presence of coumarins.

\section{Estimation of Total Phenolic Content}

The total phenolic contents of the ethanolic extracts of Phyllanthusniruri were estimated using the Folin-Ciocalteau reagent as described by Singleton and Rossi (7). Catechol was used as a reference standard. To prepare a calibration curve, aliquots of $0.2,0.4,0.6,0.8,1.0 \mathrm{ml}$ catechol solution is mixed with $2.5 \mathrm{ml}$ of Folin-Ciocalteu reagent and $2.5 \mathrm{ml}$ of sodium carbonate. After $30 \mathrm{~min}$ of incubation at $40^{\circ} \mathrm{C}$ in a water bath, the absorbance was measured at $650 \mathrm{~nm} .0 .5 \mathrm{ml}$ of plant extract was mixed with $2.5 \mathrm{ml}$ of Folin-Ciocalteu and $2.5 \mathrm{ml}$ of sodium carbonate and the absorbance 
Table 1. Phytochemical Screening of Phyllanthus niruri

\begin{tabular}{|c|c|c|c|c|}
\hline Sl. No & Phytochemicals & Test & Observation & Inference \\
\hline 1 . & Saponins & $\begin{array}{c}\text { Foam formation } \\
\text { test }\end{array}$ & Formation of foam / emulsion & Positive \\
\hline 2. & Alkaloids & $\begin{array}{l}\text { Wagner's Test } \\
\text { Hager's Test }\end{array}$ & $\begin{array}{c}\text { Reddish brown precipitate } \\
\text { Yellow precipitate }\end{array}$ & $\begin{array}{l}\text { Positive } \\
\text { Positive }\end{array}$ \\
\hline 3. & Phenols & $\begin{array}{c}\text { Ferric Chloride } \\
\text { Test }\end{array}$ & Blue colour & Positive \\
\hline 4. & Terpenoids & $\begin{array}{l}\text { Salkwoski’s } \\
\text { Test }\end{array}$ & Reddish brown ring & Positive \\
\hline 5. & Flavonoids & $\begin{array}{c}\text { Alkaline } \\
\text { Reagent Test } \\
\text { Lead Acetate } \\
\text { Test }\end{array}$ & $\begin{array}{l}\text { Yellow colour which becomes } \\
\text { colourless on the addition of } \\
\text { dilute acid. } \\
\text { Yellow precipitate }\end{array}$ & $\begin{array}{l}\text { Positive } \\
\text { Positive }\end{array}$ \\
\hline 6. & Carbohydrates & $\begin{array}{l}\text { Fehling's Test } \\
\text { Benedict's Test } \\
\text { Molisch's Test } \\
\text { Barfoed's Test } \\
\text { Seliwanoff's } \\
\text { Test }\end{array}$ & $\begin{array}{l}\text { Reddish brown precipitate } \\
\text { Orangish yellow precipitate } \\
\text { Violet ring formation } \\
\text { Precipitate formation in 1-2 } \\
\text { minutes (monosaccharide) } \\
\text { Red precipitate (ketones) }\end{array}$ & $\begin{array}{l}\text { Positive } \\
\text { Positive } \\
\text { Positive } \\
\text { Positive } \\
\text { Positive }\end{array}$ \\
\hline 7. & Amino acids & Ninhydrin Test & Purple colour & Positive \\
\hline 8. & Proteins & Biuret Test & No characteristic change & Negative \\
\hline 9. & Anthraquinone & Borntrager's Test & Pink colouration & Positive \\
\hline 10. & Cardiac Glycosides & Keller- Killani Test & No characteristic change & Negative \\
\hline 11. & Tannins & Ferric chloride Test & Bluish black colour & Positive \\
\hline 12. & Coumarins & $\begin{array}{c}\text { Sodium } \\
\text { hydroxideTest }\end{array}$ & Yellow colour & Positive \\
\hline
\end{tabular}

was measured at $650 \mathrm{~nm}$. Total Phenolic Content was expressed as milligrams of catechol equivalent per $\mathrm{g}$ of the extract. The Total Phenolic content was estimated using the formula,

$$
\mathrm{C}=\mathrm{c} \times \mathrm{V} / \mathrm{m} \text { where, }
$$

Where, $\mathrm{C}=$ total phenolic content in $\mathrm{mg} / \mathrm{g}$, in Catechol equivalents, $\mathrm{c}=$ concentration of catechol established from the calibration curve in $\mathrm{mg} / \mathrm{ml}$, $\mathrm{V}=$ volume of extract in $\mathrm{ml}$ and, $\mathrm{m}=$ the weight of the plant extract in $\mathrm{g}$.

\section{a-AMYLASE INHIBITION ASSAY OF P. niruri}

Reagents Required

(1) Phosphate Buffer

Solution A: $6.24 \mathrm{~g}$ of sodium dihydrogen phosphate dissolved in 1 litre of water

Solution B: $7.12 \mathrm{~g}$ of disodium hydrogen phosphate dissolved in 1 litre of water

(2) Substrate: $1 \%$ Starch

$1 \mathrm{~g}$ of starch dissolved in $100 \mathrm{ml}$ of distilled water, gently boiled and cooled.

(3) Enzyme (a-amylase)

$100 \mathrm{mg}$ of enzyme dissolved in $100 \mathrm{ml}$ of $40 \mathrm{mM}$ Phosphate Buffer

(4) $\mathrm{NaCl}(0.006 \mathrm{M})$

(5) Positive control: Insulin

Stock - 100mg of insulin dissolved in $100 \mathrm{ml}$ of $40 \mathrm{mM}$ Phosphate Buffer 
Table 2: Estimation of Total Phenolic Content

\begin{tabular}{|c|c|c|c|}
\hline SI. No & Volume of Working Standard (ml) & Concentration(mg/ml) & OD at 650 nm \\
\hline B & 0 & O & 0 \\
\hline S1 & 0.2 & 0.2 & 0.43 \\
\hline S2 & 0.4 & 0.4 & 0.69 \\
\hline S3 & 0.6 & 0.6 & 0.88 \\
\hline S4 & 0.8 & 0.8 & 1.30 \\
\hline S5 & 1 & 1 & 1.52 \\
\hline T & 1 & - & 1.30 \\
\hline
\end{tabular}

Table 3: a- Amylase inhibitory effects of insulin.

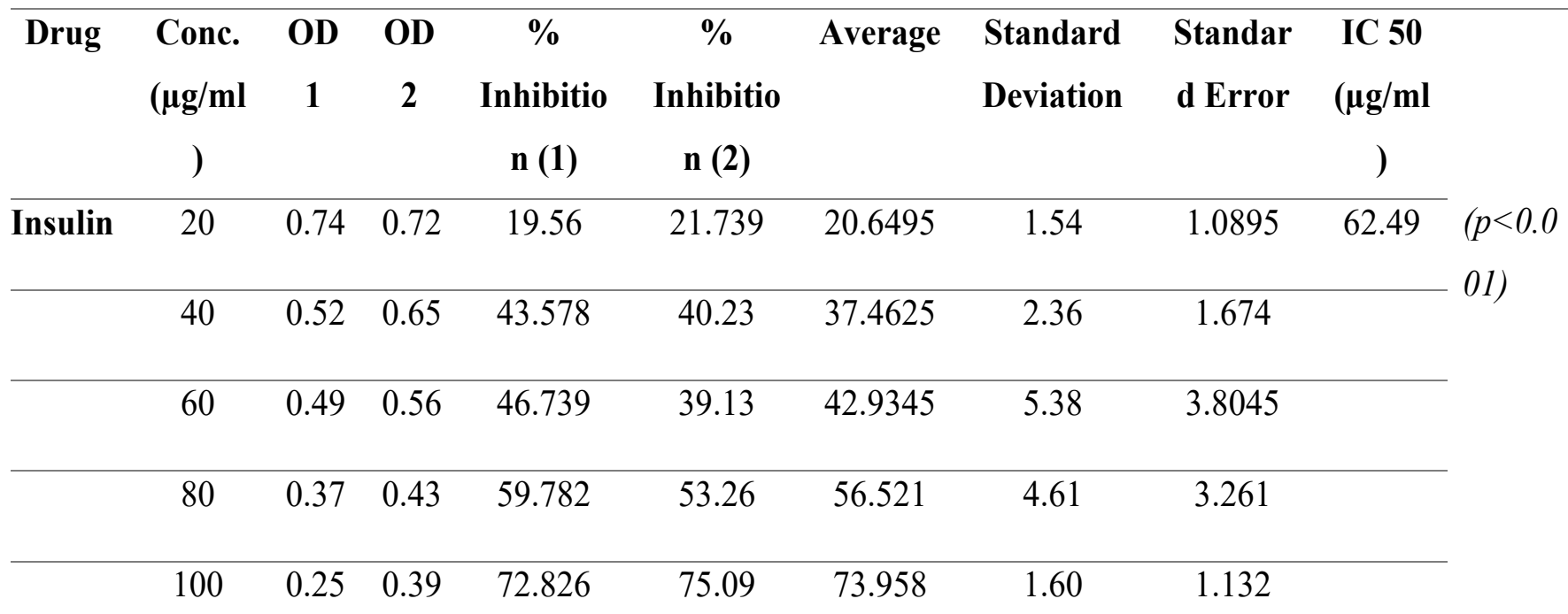

\section{(6) 3, 5-dinitrosalicylic acid (DNSA)}

The $\alpha$-amylase inhibition assay was performed using the 3,5-dinitrosalicylic acid (DNSA) method. Different concentration of the plant extract ranging from $20 \mu \mathrm{g} / \mathrm{ml}-100 \mu \mathrm{g} / \mathrm{ml}$ was prepared. A volume of $500 \mu \mathrm{l}$ of $\alpha$-amylase solution was mixed with different aliquots of the extract and was incubated for $10 \mathrm{~min}$ at $25^{\circ} \mathrm{C}$. Thereafter $500 \mu$ lof the starch solution was added to each tube and incubated for $10 \mathrm{~min}$ at $25^{\circ} \mathrm{C}$. The reaction was terminated by the addition of $1000 \mu$ l of DNSA reagent and was boiled for $10 \mathrm{~min}$ in a water bath at $85-90{ }^{\circ} \mathrm{C}$. The mixture was cooled to ambient temperature and was diluted with $5 \mathrm{ml}$ of distilled water, and the absorbance was measured at $540 \mathrm{~nm}$. A control with $100 \%$ enzyme activity was prepared by replacing the plant extract with $200 \mu \mathrm{l}$ of buffer. A positive control sample was prepared using Insulin $(20 \mu \mathrm{g} / \mathrm{ml}-100 \mu \mathrm{g} / \mathrm{ml})$ and the reaction was performed similarly to the reaction with plant extract as mentioned above. The a-amylase inhibitory activity was expressed as percent inhibition and was calculated using the equation given below: The $\%$ a-amylase inhibition
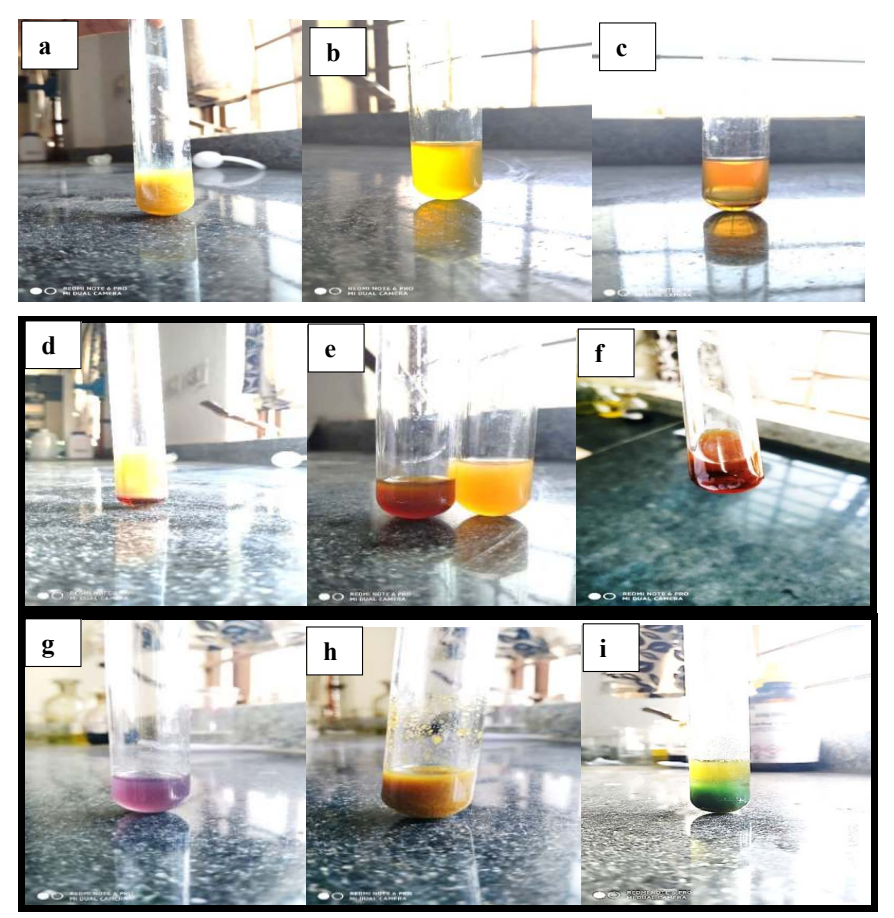


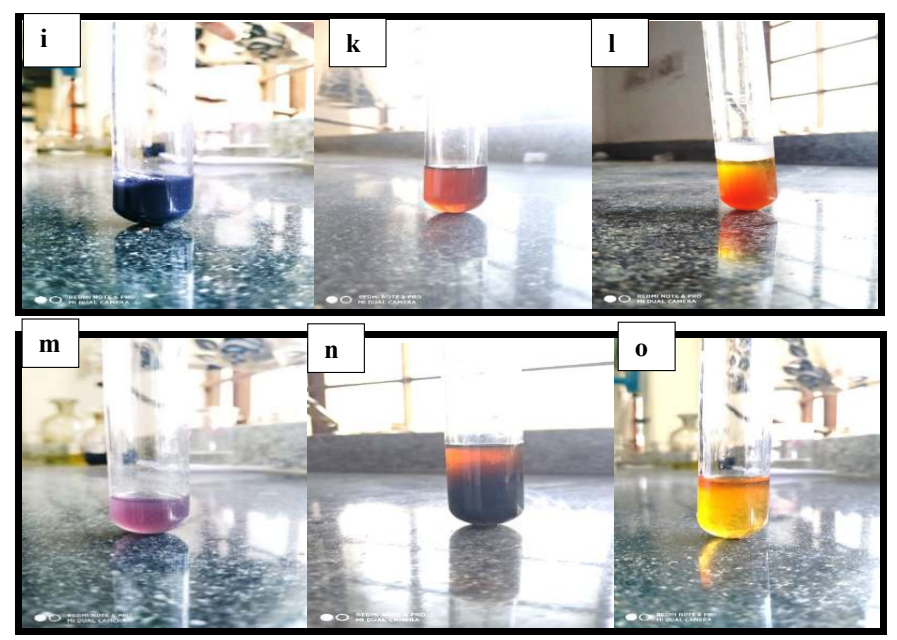

Fig.1: Phytochemical screening (a) appearance of foam indicates the presence of saponins.(b) appearance of reddish-brown precipitate indicates presence of alkaloids.(c) formation of yellow ppt indicates presence of alkaloids.(d) formation of blue colour indicates presence of phenols. (e) formation of a reddish -brown ring indicates the presence of terpenoids.(f) disappearance of yellow colour on addition of dilute acid indicates presence of flavonoids. (g) appearance of yellow colour indicates presence of flavonoids.(h) appearance of brick red precipitate indicates presence of carbohydrates.(i) formation of orange- yellow precipitate shows presence of reducing sugar.(j) formation of violet ring indicates presence of carbohydrates.(k) formation of precipitate indicates presence of monosaccharides.(l) formation of red colour indicates presence of sugars (ketone) ( $\mathrm{m}$ ) formation of a purple colour indicates presence of amino acids. (n) formation of pink colouration indicates presence of anthraquinone.(0) no characteristic change indicates absence of cardiac glycosides.

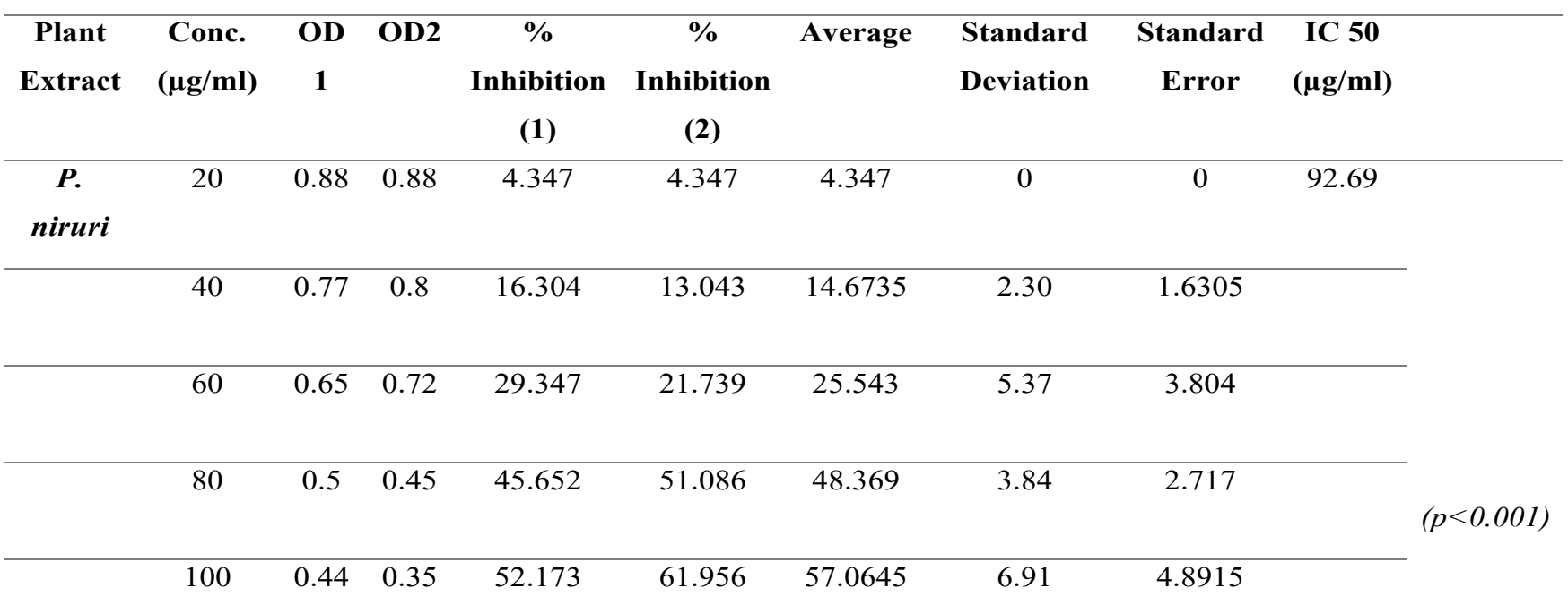

was plotted against the concentration and the $\mathrm{IC}_{50}$ values were obtained from the graph (8)

$\%$ inhibition $=\frac{\text { Absorbance of control }- \text { Absorbance of sample }}{\text { Absorbance of control }} \times 100$

\section{RESULTS}

\section{PHYTOCHEMICAL SCREENING OF PHYLLANTHUS NIRURI}

The phytochemicals are chemicals of plant origin, they are produced by plants through primary / secondary metabolism. The phytochemical screening of methanolic extracts of Phyllanthus niruri is shown in the Table 1.

The results showed thepresence of saponins, alkaloids, tannins, flavonoids, phenols, terpenoids, carbohydrates, coumarins, anthraquinones and amino acids. The phytochemicals like phenols, flavonoids, saponins, terpenoids can scavenge free radicals. These compounds have previously shown strong anti-cancer, anti-diabetic, anti-inflammatory and anti-microbial activity.

\section{Determination of Total Phenolic Content}

TPC activity is the process to figure out the phenolic content in plants. Phenolic compounds contained in the plants have redox properties and these properties allow them to act as antioxidants. The hydroxyl group in plant extract are responsible for facilitating free radical scavenging. The total phenolic concentration could be used as a basis for rapid screening of antioxidant activity. The Phenolic content was measured using Folin- Ciocalteu's reagent and the colour intensity was measured at 650nm. (Table 2)

The total phenolic content was measured using Catechol (standard) and a graph was plotted with concentration on $X$ axis and absorbance on the $Y$ axis. The results were derived from the calibration curve $y=$ $1.395 x+0.127, R^{2}=0.9862$ of catechol $(0.2-1 \mathrm{mg} / \mathrm{ml})$ and expressed in Catechol equivalents per gram dry extract weight. The total phenolic content was calculated using the formula $\mathrm{C}=\mathrm{c} \times \mathrm{V} / \mathrm{M}$. The total phenolic content in the extracts of Phyllanthus niruri was found to be 8.4 $\mathrm{mg}$ Catechol/g. (Fig 2)

\section{In Vitro a - Amylase Inhibitory Assay}

The antidiabetic activity of insulin and Phyllanthus 


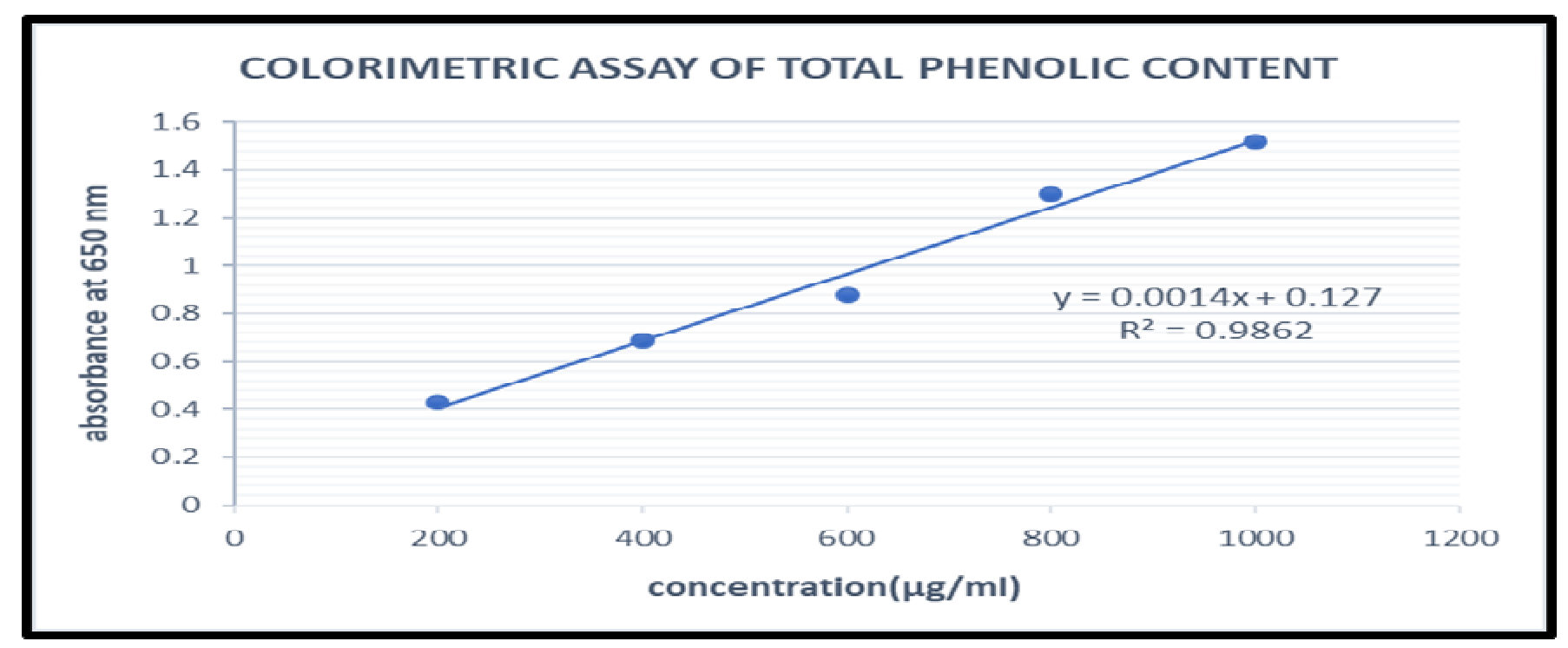

Fig 2. Graph for estimation of Total Phenolic Content

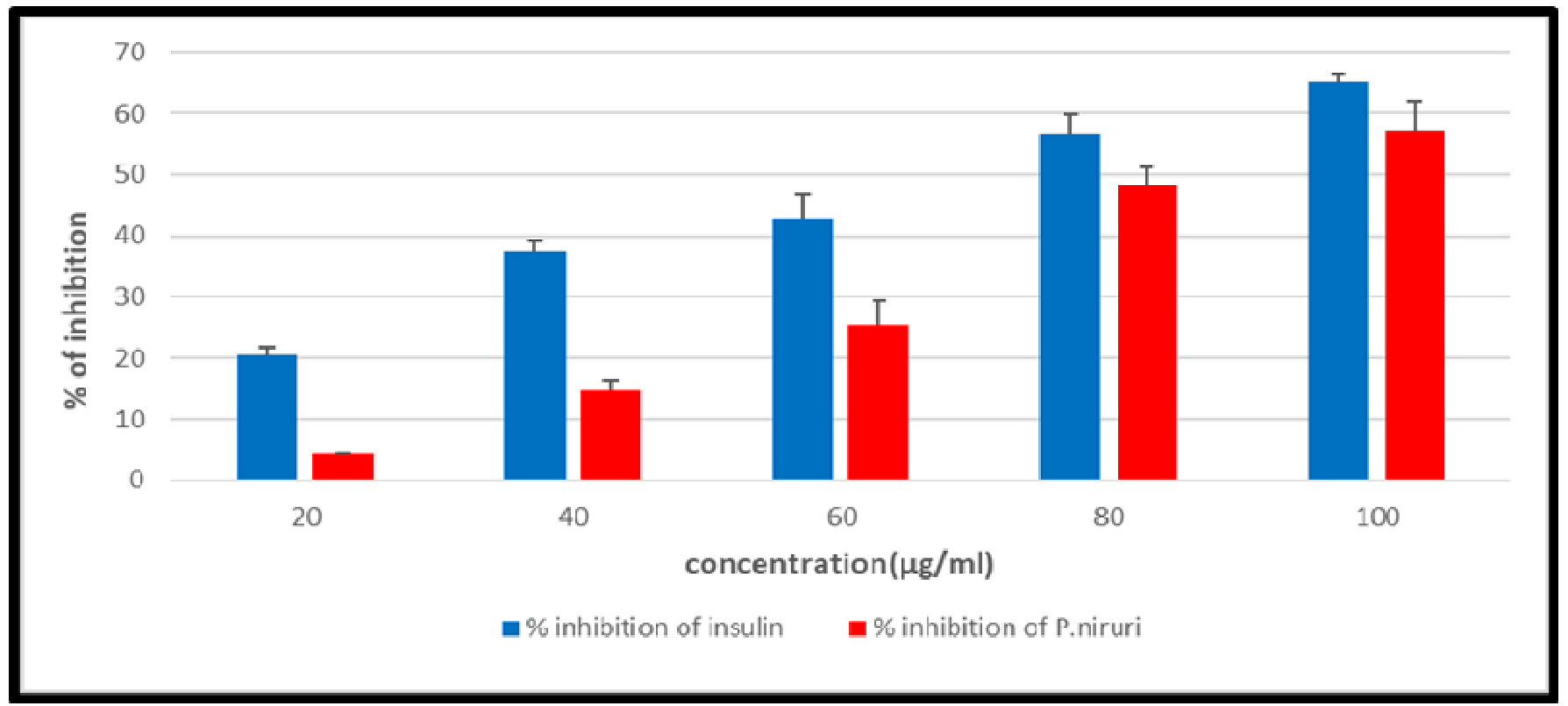

Fig.3. Bar Graph representing a- Amylase Inhibition of Insulin and Phyllanthus niruri.

niruri was investigated through inhibition of $\alpha$-amylase enzyme. The inhibition percentage was calculated using the formula,

$\%$ inhibition $=\frac{\text { Absorbance of control }- \text { Absorbance of sample }}{\text { Absorbance of control }} \times 100$

The half maximal inhibitory concentration (IC 50) is a measure of the potency of a substance in inhibiting a specific biological or biochemical function. The IC50 value was calculated from the calibration curves of a-amylase inhibition of Insulin and $P$. niruri. The OD value of control was found to be 0.92 . The calibration curve for Insulin was $y=0.6141 x+11.623, R^{2}=0.9521$. The calibration curve for $P$. niruri was $y=0.6251 x-$ $7.943, R^{2}=0.9878$. The standard drug insulin at highest concentration $(100 \mu \mathrm{g} / \mathrm{ml})$ showed $72.82 \%$ inhibitory effects on the $\alpha$-amylase activity with an IC50 value $62.49(\mu \mathrm{g} / \mathrm{ml})$ (table 1$)$. The ethanolic extracts of $P$. niruri at highest concentration showed $52.17 \%$ inhibitory effect on $\alpha$ - amylase activity with an IC50 value $92.69(\mu \mathrm{g} / \mathrm{ml})$ (Table 3 \& 4).(Fig.3,4 and 5)

\section{Statistical analysis of $\alpha$-amylase inhibition assay}

The inhibition of $\alpha$-amylase by the plant extract and insulin (standard control) was found to highly significant with the $p$-value $<0.001$ analysed by one-way ANNOVA test.

\section{Discussion}

Phyllanthus niruri is an important medicinal plant which has been used in ayurvedic medicine in the treatment of diseases for over 2000 years [9]. The plant is also used in traditional medicine for treatment of diseases. Scientific investigation of this medicinal 


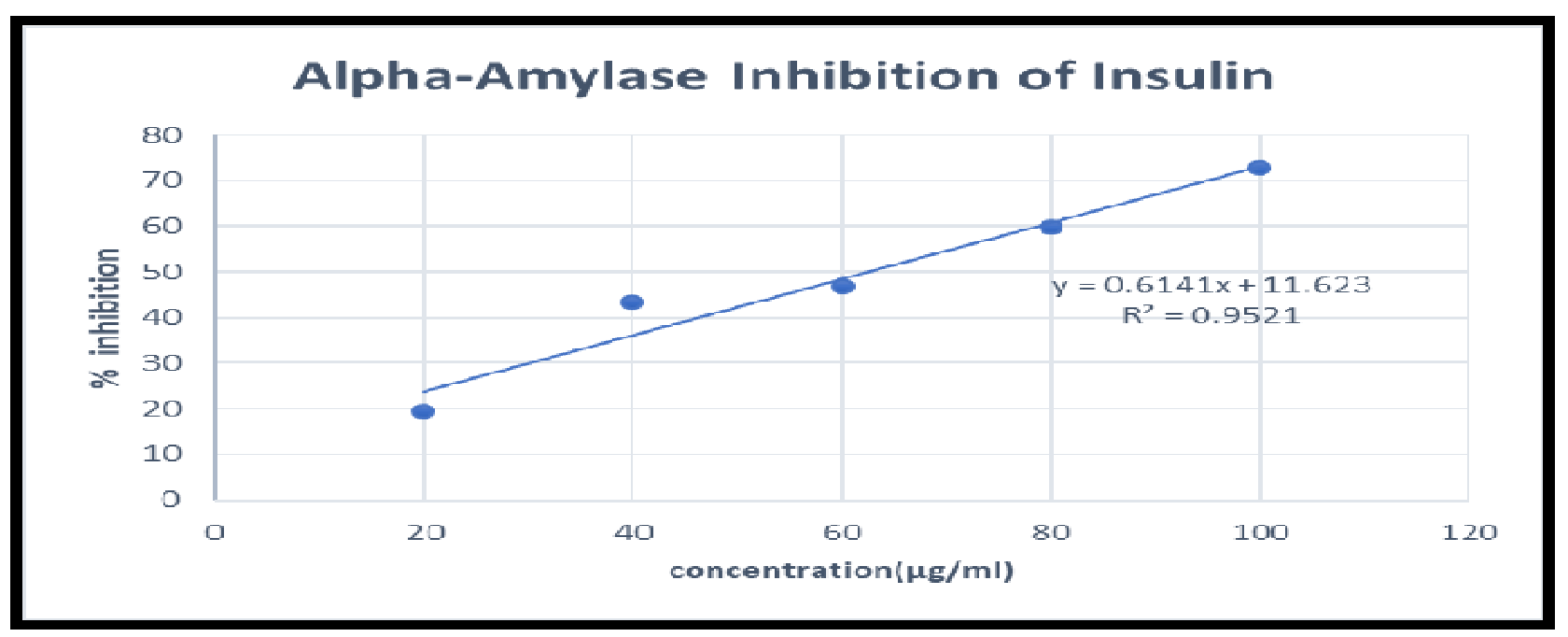

Fig.4. Graph for inhibition of $\alpha$ - amylase by insulin.

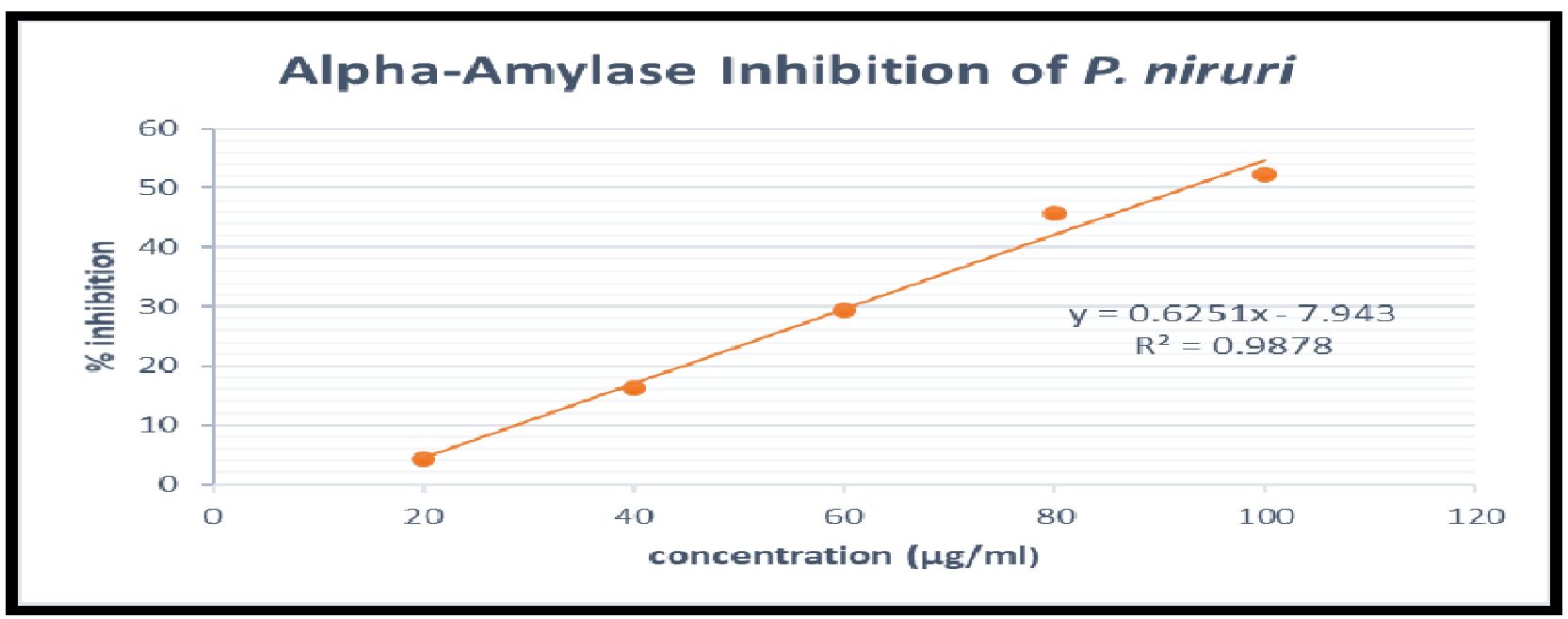

Fig.5. Graph for inhibition of $\alpha$-amylase by P. niruri

plant revealed that the plant contains several chemicalconstituents and these were found to be active against some diseases. For example, phyllanthin is a chemical compound isolated from Phyllanthus niruri, and reported to have hepatoprotective activity. This activity is associated with its radical scavenging activity (10). Phyllanthus niruri has been used for years in different parts of the world for liver problem. The Aqueous extract of Phyllanthus niruri has also been used by Brazilians as traditional medicine for the treatment of kidney stone disease as well as for jaundice and hepatitis (11). Previous studies on the plant extract showed the presence of Saponins, Alkaloids, Phenols, Terpenoids, and Flavonoids (12).

Preliminary qualitative phytochemical analysis of $P$. niruri revealed the presence of Alkaloids, Flavonoids, Phenols, Tannins, Saponins, Terpenoids, Carbohydrates, Amino acids, Anthraquinone, Coumarins. These secondary metabolites are reported to have many biologicaland therapeutic properties.Alkaloids havea wide range of pharmacological activities including antimalarial and anticancer. Phenols and Flavonoids have significant antioxidant properties. Phenols are associated with the ability to inhibit the growth of bacteria (13). Saponins also have a wide range of pharmaceutical properties like antifungal, anti-inflammatory, antiparasitic. Terpenoids are biologically active against infectious diseases and cancer. Coumarins have a variety of biological properties like anti-microbial, antiviral, antidiabetic, antioxidant, enzyme inhibitory activity. Anthraquinone used as laxative ad possess antifungal and antiviral activities.

Many herbal extracts have been reported to have antidiabetic activities and are used in Ayurveda for the treatment of diabetes. Herbal extracts have been used directly or indirectly for the preparation of many modern medicines. In this study, an in vitro inhibitory effect of different concentrations of P. niruri on alpha-amylase was evaluated.One of the strategies and methods adopted to cure diabetes mellitus involves the inhibition of carbohydrate digesting enzymes such as a-amylase and $\alpha$-glucosidase in the gastrointestinal glucose absorption thereby lowering postprandial glucose level [McCue, et al., 2005]. $\alpha$-amylase and $\alpha$-glucosidase are key enzymes involve in carbohydrates breakdown and intestinal absorption, respectively. Inhibition of these 
enzymes hamper blood glucose level increased after a carbohydrates diet and can be an important strategy in the management of non-insulin-dependent diabetes mellitus (14). Alpha-amylase catalyses the hydrolysis of alpha-1,4-glycosidic linkages of starch, glycogen and various oligosaccharides. Alpha-glucosidase further breaks down the disaccharides to simple sugars, readily available for intestinal absorption. The inhibition of their activity in the digestive tract of humans is and considered to be effective tool to control diabetes. In addition, these effects may lead to diminished absorption of monosaccharides. Therefore, an effective, nontoxic inhibitors of alpha-amylase and alpha-glucosidase have long been sought.

The plant extract of $P$. niruri showed potent inhibition of Alpha - Amylase activity. In our study the ethanolic extracts of Phyllanthus niruri (at concentration of $100 \mu \mathrm{g} /$ $\mathrm{ml}$ ) showed $57.064 \%$ of alpha amylase inhibitory activity with an IC 50 value of $92.69 \mu \mathrm{g} / \mathrm{ml}$. The previous studies about the antidiabetic activity of $P$. niruri was evaluated in alloxan diabetic rats using blood glucose lowering and post- prandial glucose suppression activities. The results of the above study showed that the extract lowered the blood glucose level, suppressed the postprandial rise in blood glucose following a glucose meal (15).

\section{References}

1. Burkill I.H., et al. (1966). A dictionary of the economic products of Malay Peninsula, Kuala Lumpur, Malaysia

2. Verspohl, E. J. (2002). Recommended testing in diabetes research. Planta medica, 68(07), 581590.

3. 3. Amos, S., Chindo, B., Edmond, I., Akah, P., Wambebe, C., \& Gamaniel, K. (2002). Antiinflammatory and anti-nociceptive effects of Ficus platyphylla extract in mice and rats. Journal of herbs, spices \& medicinal plants, 9(1), 47-53.

4. Bnouham, M., Ziyyat, A., Mekhfi, H., Tahri, A., \& Legssyer, A. (2006). Medicinal plants with potential antidiabetic activity-A review of ten years of herbal medicine research (1990-2000). International Journal of Diabetes and Metabolism, 14(1), 1.

5. Tadera, K., Minami, Y., Takamatsu, K., \& Matsuoka, T. (2006). Inhibition of $\alpha$-glucosidase and $\alpha$-amylase by flavonoids. Journal of nutritional science and vitaminology, 52(2), 149-153.

6. Lo Piparo, E., Scheib, H., Frei, N., Williamson, G., Grigorov, M., \& Chou, C. J. (2008). Flavonoids for controlling starch digestion: structural requirements for inhibiting human $\alpha$-amylase. Journal of medicinal chemistry, 51(12), 3555-3561.
7. Singleton, V., et al. (1965) "Colourimetry of Total Phenolics with Phosphomolybdic- Phosphotungstic Acid Reagents." American Journal of Enology and Viticulture. 16(3):144-158.

8. Wickramaratne, Nirmali, et al. (2016) In- vitro alpha amylase inhibitory activity of leaf extracts of Adenanthera pavonina. BMC Complementary Medicine and therapies. 16: 466.

9. Adedapo1, A.A., etal. (2005) Some Clinicopathological Changes associated with the Aqueous Extract of the Leaves of Phyllanthus amarus in Rats. Phytother Res., 19(11): 971-976.

10. Rajesh, Krithika, et al. (2009) "Isolation, characterization and antioxidative effect of Phyllanthin against CCl4-induced toxicity in HepG2 cell line." Chemico-Biological interactions. 181(3): 351-358.

11. Ishimaru Kanji, et al. (1992) Phenolic constituents in Tissue Cultures of Phyllanthus niruri. Phytochemistry., 31(6): 2015-2018.

12. Kaur, Ramandeep, et al. (2017) Phytochemical Screening of Phyllanthus niruri collected from Kerala region and its Antioxidant and Antimicrobial Potentials. Journal of PharmaceuticalsSciences and Research, 8(8): 1312-1316.

13. Chan, Eric, et al. (2011) Antioxidant and antibacterial properties of green, black, and herbal teas of Camelliasinensis.Pharmacognosy Res.,3(4):266272

14. Sulaiman, Al-Zuhair, et al. (2010) "Inhibitory effect of dates extracts on $\alpha$ - amylase and $\alpha$-glucosidase enzymes relevant to non-insulin dependent diabetes mellitus." Journal of Biochemistry, Technology., 2(2):158-160.

15. Okoli, C. O., et al. (2011) Studies on Possible Mechanism of Antidiabetic activity of extracts of Aerial Parts of Phyllanthus niruri,Pharma Biol. 49(3): 248-255 